
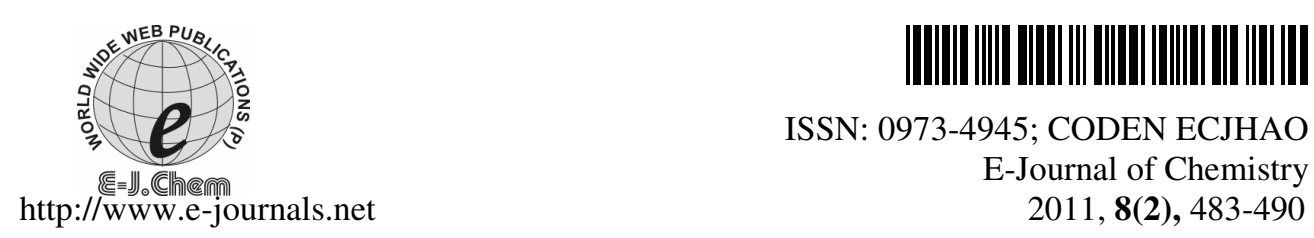

ISSN: 0973-4945; CODEN ECJHAO

E-Journal of Chemistry

2011, 8(2), 483-490

\title{
Stability-Indicating RP-HPLC Method for Assay of Silver Lactate
}

\author{
V. SRINIVASAN ${ }^{\S *}$, H. SIVARAMAKRISHNAN and B. KARTHIKEYAN ${ }^{\S}$ \\ Department of Analytical Development \\ Piramal Healthcare Ltd, Ennore, Chennai-600 057, India \\ $\S$ Department of Chemistry \\ Annamalai University, Annamalainagar-608002, India \\ vsvnreddy@yahoo.com
}

Received 27 March 2010; Revised 31 May 2010; Accepted 17 July 2010

\begin{abstract}
A simple, economic and time-efficient stability-indicating, reversephase high-performance liquid chromatographic (RP-HPLC) method has been developed for analysis of silver lactate in the presence of degradation products generated by decomposition. When silver lactate was subjected to acid hydrolysis, base hydrolysis, oxidative, photolytic, humidity and thermal stress, degradation was observed during base hydrolysis, oxidation, humidity and thermal stress. The drug was found to be stable to other stress conditions. Successful chromatographic condition of the drug from the degradation products formed under stress conditions was achieved on a Phenomenex Gemini column with potassium dihydrogen phosphate buffer, $\mathrm{pH}$ adjusted to 2.2 with orthophosphoric acid, as mobile phase. The method was validated for linearity, precision, specificity and robustness and can be used for quality-control during manufacture and assessment of the stability of samples of silver lactate. To the best of our knowledge, a validated stability-indicating LC assay method for silver lactate based on lactic acid is reported for the first time.
\end{abstract}

Keywords: RP-HPLC, Silver lactate, Lactic acid, Degradation products

\section{Introduction}

Silver lactate chemically 2-hydroxypropanoic acid silver salt ${ }^{1}$ has the molecular formula $\mathrm{C}_{3} \mathrm{H}_{5} \mathrm{AgO}_{3}$ and molecular weight 196.94. Silver lactate is a drug which is used as antimicrobial agent in the external application ${ }^{2}$. Its application in the treatment of thermal burn has been reported. Silver lactate is an ideal base for bactericidal agents in the treatment of full thickness thermal wound ${ }^{3-4}$. With the experience accumulated from more than a century of silver applications in biology and medicine, physical development has become a powerful bio-analytical tool for marker amplification in blotting procedures, in situ hybridization 
and histochemistry. To accommodate the modern demand for accurate physical development, various strategies have been devised; one among them is changing to silver lactate ${ }^{5}$. Silver lactate also finds application as stainer in the study of fungal by electron microscope ${ }^{6}$.

The different analytical techniques reported so far for analysis of lactic acid in biological samples and in pharmaceutical formulations includes electrophoresis ${ }^{7}, \mathrm{NMR}^{8}$, NIR $^{9}$. Several HPLC methods for assay and LC-MS-MS method for analysis of lactic acid have previously been published ${ }^{10-13}$.

This paper describes a simple isocratic reverse-phase HPLC method that separates silver, lactic acid and degradation products. Assay of silver lactate is calculated based on the lactic acid peak. To the best of our knowledge no such report on the validation of assay of silver lactate has been taken, hence we have taken this study. The structures of silver lactate and chromatographic separation of the compounds are illustrated in Figure 1.

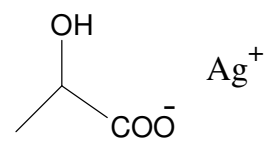

Mol. Wt.: 196.94

Figure 1. Chemical structure of silver lactate

The process for the synthesis of silver lactate has recently been developed in our laboratory; an RP-HPLC method was developed for analysis of silver lactate. The specificity, linearity, precision and robustness of the method were determined in accordance with ICH guidelines ${ }^{14}$. This paper reports, for the first time, a rapid, efficient, simple and validated stability-indicating RP-HPLC method for assay of silver lactate.

\section{Experimental}

Sample of silver lactate was synthesized in our laboratory and characterized by use of IR and NMR. All the reagents used were of analytical reagent grade unless stated otherwise. Orthophosphoric acid spectroscopic grade was purchased from Merck. Lactic acid from Lancaster synthesis grade having $98+\%$ is used as reference standard.

\section{Instrumentation and chromatographic conditions}

HPLC was performed with quaternary gradient pumps, an auto sampler and an auto injector (model 1200;Agilent, USA) connected to a photodiode-array detector, all were controlled by Empower software (Waters). Chromatographic separation was achieved on a Phenomenex Gemini $\mathrm{C} 18,250 \times 4.6 \mathrm{~mm}, 5 \mu \mathrm{m}$ particle, with potassium dihydrogen phosphate, $\mathrm{pH}$ adjusted to 2.2 with orthophosphoric acid, as mobile phase. Before use, the mobile phase was filtered through a $0.2 \mu \mathrm{m}$ PTFE filter and degassed by ultrasonication for $15 \mathrm{~min}$. The injection volume was $10 \mu \mathrm{L}$, the mobile phase flow rate was $1.0 \mathrm{~mL} \mathrm{~min}{ }^{-1}$, the column temperature was $30{ }^{\circ} \mathrm{C}$ and detection was at $210 \mathrm{~nm}$.

\section{Preparation of working solutions}

The standard and test concentration for the assay were $7 \mathrm{mg} \mathrm{mL} L^{-1}$ and $15 \mathrm{mg} \mathrm{mL}^{-1}$ respectively. Standard and test dilutions were prepared in water.

\section{Forced degradation studies (stress testing)}

Silver lactate was deliberately subjected to stress to establish the stability-indicating nature and specificity of the method. The drug was exposed to UV light $(254 \mathrm{~nm})$, heat $\left(80^{\circ} \mathrm{C}\right)$, 
acid $\left(5.0 \mathrm{~N} \mathrm{HCl}, 60{ }^{\circ} \mathrm{C}\right)$, alkali $\left(1.0 \mathrm{~N} \mathrm{NaOH}, 25{ }^{\circ} \mathrm{C}\right)$, oxidation $\left(30.0 \% \mathrm{H}_{2} \mathrm{O}_{2}\right.$ for $\left.12 \mathrm{H}\right)$ and Humidity $\left(95 \% \mathrm{RH}, 25{ }^{\circ} \mathrm{C}\right)$ to evaluate the ability of the method to separate silver lactate from its degradation products. For heat and light stress the study period was $72 \mathrm{~h}$; for acidic $30 \mathrm{~min}$, alkaline $20 \mathrm{~min}$ and oxidative stress it was $12 \mathrm{~h}$. Peak purity testing was performed for the lactic acid peak obtained from stress samples by use of the PDA detector. Assay studies of stressed samples were performed by comparison with lactic acid reference standard.

\section{Precision}

The precision of the method was assessed by performing six independent assays of silver lactate test sample $\left(15 \mathrm{mg} \mathrm{mL}^{-1}\right)$ in comparison with lactic acid reference standard $\left(7 \mathrm{mg} \mathrm{mL}^{-1}\right)$ and calculating the RSD (\%) of the assay. The intermediate precision was assessed for the method by performing assay by a different analyst using a different instrument with different lot number HPLC column in the same laboratory.

\section{Linearity}

Solutions for testing the linearity of the assay method were prepared for silver lactate sample and lactic acid reference standard at five concentrations from 80 to $120 \%$ of the nominal assay concentration of the sample $\left(12,13.5,15,16.5\right.$ and $\left.18 \mathrm{mg} \mathrm{mL}^{-1}\right)$ and lactic acid standard $\left(5.6,6.3,7.0,7.7\right.$ and $\left.8.4 \mathrm{mg} \mathrm{mL}^{-1}\right)$ respectively. Peak area and concentration data were treated by least squares linear regression analysis. These tests were conducted and correlation coefficient was calculated between concentration verses area. Linearity calculations were performed with Microsoft Excel.

\section{Robustness}

To assess the robustness of the method, experimental conditions were deliberately altered and assay was recorded. The effect of flow rate was studied by varying the flow rate by $\pm 0.1 \mathrm{~mL} \mathrm{~min}^{-1}$. The effect of column temperature was studied by varying the temperature by $\pm 5.0^{\circ} \mathrm{C}$. The effect of $\mathrm{pH}$ was studied by varying the $\mathrm{pH}$ by \pm 0.2 units. The effect of wavelength was studied by varying the wavelength by $\pm 5.0 \mathrm{~nm}$. In all tests the other conditions were held constant.

\section{Solution stability}

The solution stability of silver lactate in the assay method was carried out by leaving test solutions of sample and reference standard in water in tightly capped volumetric flasks at room temperature for $24 \mathrm{~h}$. Area of the lactic acid in sample solution and in the standard solution were determined every $4 \mathrm{~h}$. Cumulative RSD was calculated.

\section{Results and Discussion}

\section{Optimization of chromatographic conditions}

The main objective of the chromatographic method was to determine the assay of silver lactate. Chromatographic separation was achieved on a phenomenex Gemini C18, 250x4.6 mm, $5 \mu \mathrm{m}$ particle, with potassium dihydrogen phosphate, $\mathrm{pH}$ adjusted to 2.2 with orthophosphoric acid, as mobile phase. The injection volume was $10 \mu \mathrm{L}$, the mobile phase flow rate was $1.0 \mathrm{~mL} \mathrm{~min}^{-1}$, the column temperature was $30{ }^{\circ} \mathrm{C}$ and detection was at $210 \mathrm{~nm}$. Peak shape of lactic acid was symmetrical. Under the optimized conditions typical retention times of lactic acid was approximately 3.0 minutes (Figure 2). The method was specific for silver lactate. 


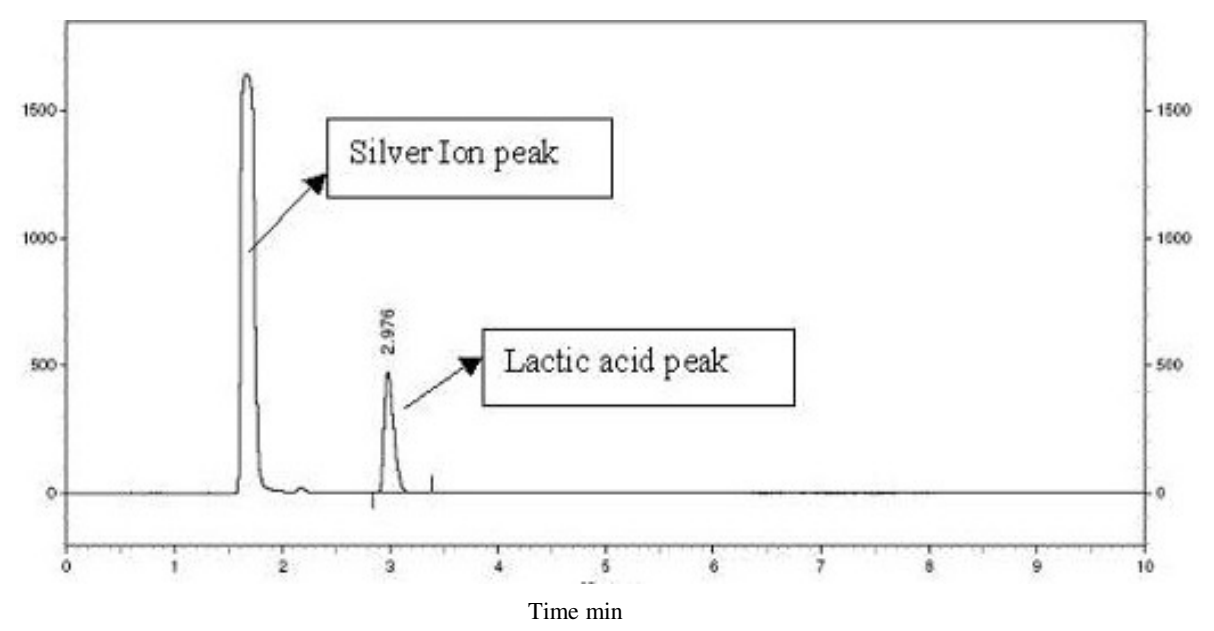

Figure 2. Chromatogram showing resolution of silver ion and lactic acid

\section{Analysis of stressed samples}

Degradation was not observed when silver lactate exposed to acid hydrolysis. Silver lactate was degraded when exposed to alkali, peroxide, thermal, humidity and UV (Figure 3a-d). Results from peak purity testing confirmed the lactic acid peak obtained by analysis of all the stress samples was homogenous and pure. Assay of silver lactate was unaffected by the presence of its degradation products, confirming the stabilityindicating nature of the method. The results from forced degradation studies are summarized in Table 1.
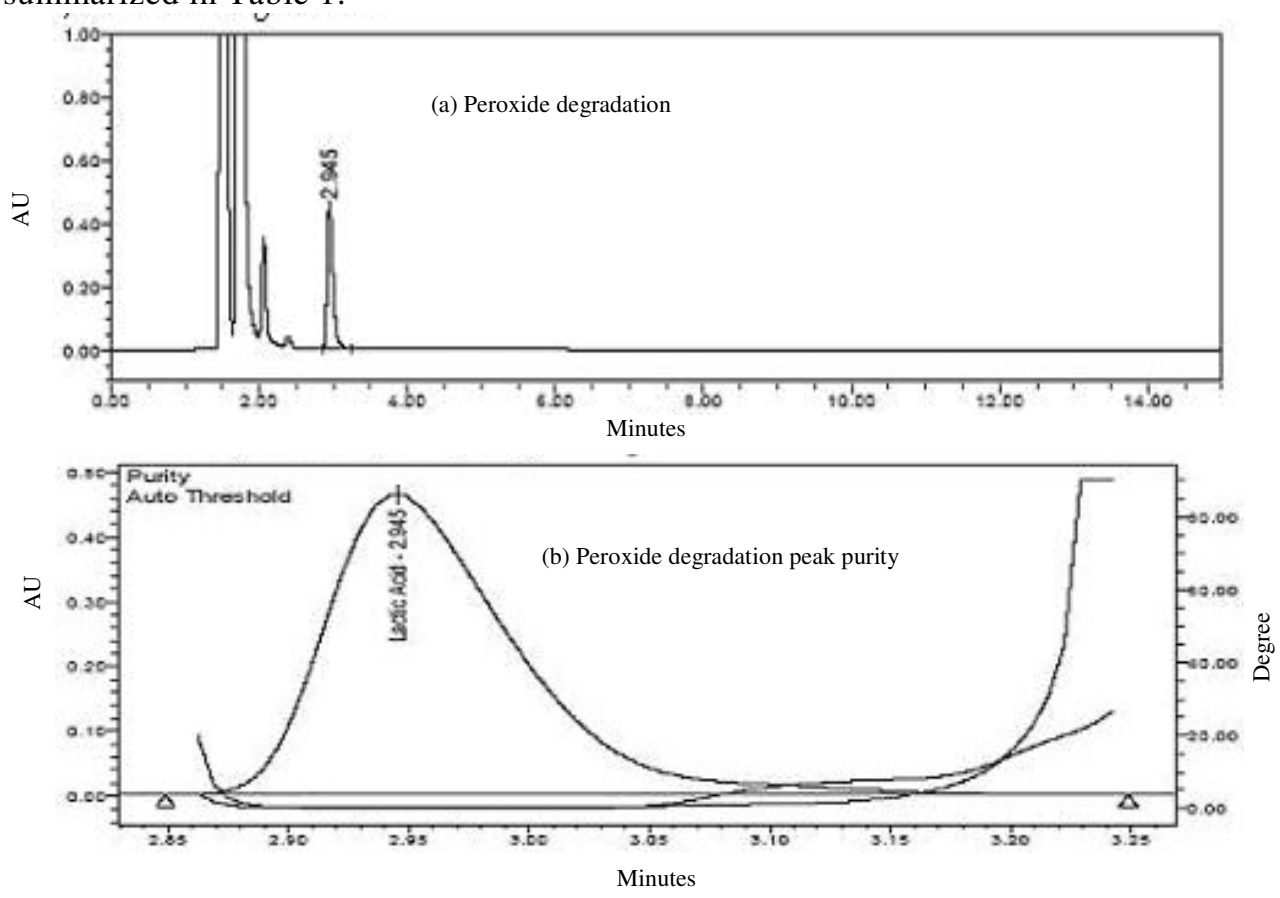

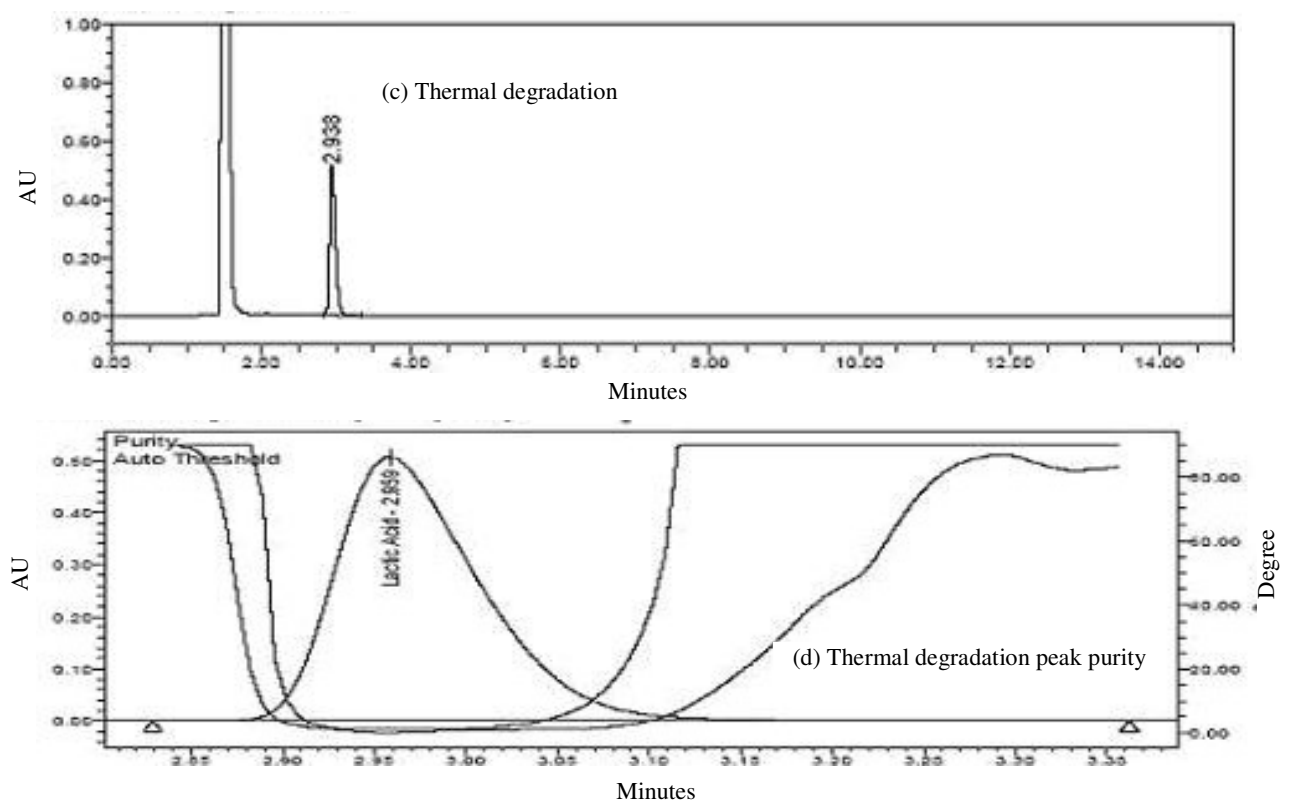

Figure 3. Chromatograms (a) and (c) for samples obtained from peroxide and humidity stress testing, (b) and (d) peak purity of peroxide and humidity stress testing

Table 1. Summary of results from forced degradation

\begin{tabular}{|c|c|c|c|c|c|}
\hline \multirow{2}{*}{$\begin{array}{l}\text { Sample without } \\
\text { treatment } \\
\text { (as such) }\end{array}$} & \multirow{2}{*}{$\begin{array}{c}\text { Assay, } \% \text { w/w on as is } \\
\text { basis } \\
99.0 \%\end{array}$} & \multicolumn{4}{|c|}{ Peak purity } \\
\hline & & \multicolumn{2}{|c|}{$\begin{array}{c}\text { Purity angle } \\
0.770\end{array}$} & \multicolumn{2}{|c|}{$\begin{array}{c}\text { Purity Threshold } \\
2.280 \\
\end{array}$} \\
\hline \multicolumn{6}{|c|}{ Stress Conditions } \\
\hline \multirow[b]{2}{*}{ Samples } & \multirow[b]{2}{*}{ Condition } & \multirow{2}{*}{ 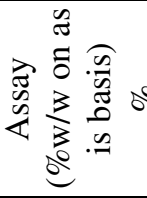 } & \multirow{2}{*}{ 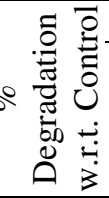 } & \multicolumn{2}{|c|}{ Peak Purity } \\
\hline & & & & $\begin{array}{l}\text { Purity } \\
\text { angle }\end{array}$ & $\begin{array}{c}\text { Purity } \\
\text { Threshold }\end{array}$ \\
\hline Acid Degradation & $\begin{array}{c}2 \mathrm{~mL} 5 \mathrm{~N} \mathrm{HCl} / 60^{\circ} \mathrm{C} \\
/ 30 \mathrm{~min}\end{array}$ & 97.1 & 2 & 0.223 & 0.306 \\
\hline Alkali Degradation & $\begin{array}{c}1 \mathrm{~mL} 1 \mathrm{~N} \mathrm{NaOH} / \\
20 \mathrm{~min}\end{array}$ & 89.2 & 10 & 0.168 & 1.871 \\
\hline Peroxide Degradation & 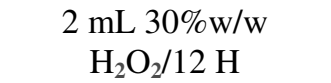 & 81.8 & 17 & 0.237 & 0.294 \\
\hline Thermal Degradation & $60^{\circ} \mathrm{C} / 72 \mathrm{H}$ & 89.6 & 9 & 0.776 & 2.328 \\
\hline Humidity Degradation & $25^{\circ} \mathrm{C} / 95 \% \mathrm{RH} / 72 \mathrm{H}$ & 93.4 & 6 & 0.801 & 3.140 \\
\hline $\begin{array}{l}\text { UV light Solid (Shorter } \\
\text { wave length) }\end{array}$ & $72 \mathrm{H}$ & 90.5 & 9 & 0.760 & 2.496 \\
\hline $\begin{array}{l}\text { UV light Solution } \\
\text { (Shorter wave length) }\end{array}$ & $72 \mathrm{H}$ & 98.4 & 1 & 0.744 & 2.061 \\
\hline White light Solid & $72 \mathrm{H}$ & 92.7 & 6 & 0.668 & 1.884 \\
\hline White light Solution & $72 \mathrm{H}$ & 98.2 & 1 & 1.024 & 3.028 \\
\hline
\end{tabular}




\section{Precision}

In the study of the precision of the assay method RSD of the peak area for assay of silver lactate was $0.20 \%$ or better. RSD of peak area in the intermediate precision study was $0.26 \%$ or better confirming the high precision of the method. Results are summarized in Table 2.

Table 2. Summary of precision results

\begin{tabular}{cc}
\hline S.No. & Area of lactic acid peak \\
\hline 1 & 3179030 \\
2 & 3177782 \\
3 & 3177938 \\
4 & 3175906 \\
5 & 3173636 \\
6 & 3173746 \\
Mean & 3176340 \\
SD & 2285 \\
\% RSD & 0.07 \\
\hline
\end{tabular}

\section{Linearity}

In the assay method a linear relationship was obtained between response and concentration over the calibration range tested, ie. $12-18 \mathrm{mg} \mathrm{mL}^{-1}$ for silver lactate sample and 5.6-8.5 mg mL for lactic acid standard The correlation coefficient was $>0.999$ for both sample and standard. Results are summarized in Table 3.

Table 3. Linearity of lactic acid peak in silver lactate sample

\begin{tabular}{lcc}
\hline Sample Name & $\begin{array}{c}\text { Concentration of Silver } \\
\text { lactate sample, } \mathrm{mg} / \mathrm{mL}\end{array}$ & $\begin{array}{c}\text { Mean area of silver lactate } \\
\text { peak }\end{array}$ \\
\hline Linearity, $80 \%$ & 12.02 & 2372220 \\
Linearity, 90\% & 13.52 & 2679345 \\
Linearity, 100\% & 15.02 & 3026444 \\
Linearity, 110\% & 16.53 & 3324259 \\
Linearity, 120\% & 18.03 & 3633338 \\
Slope & & 210719 \\
Intercept & & -158716 \\
Correlation coefficient & & 0.9997 \\
\hline
\end{tabular}

\section{Robustness}

When the chromatographic conditions flow rate, column temperature, mobile phase $\mathrm{pH}$ and wavelength were deliberately varied, cumulative RSD was $0.28 \%$ for the sample. The asymmetry of the lactic acid peak was always found less than 2.0. This illustrates that the method is robust. Results are summarized in Table 4.

Table 4. Summary of results from robustness studies

\begin{tabular}{|c|c|c|}
\hline Parameter & Condition & Assay, \%w/w. \% sfab ${ }^{*}$ \\
\hline Set - 1 & Method precision & 100.9 \\
\hline Set - 2 & Flow plus & 101.6 \\
\hline Set - 3 & Flow minus & 101.7 \\
\hline Set -4 & Temp.plus & 101.3 \\
\hline Set -5 & Temp.minus & 101.4 \\
\hline
\end{tabular}




\begin{tabular}{ccc}
\hline Set -6 & pH plus & 101.7 \\
Set -7 & pH minus & 101.8 \\
Set -8 & Wavelength plus & 101.3 \\
Set -9 & Wavelength minus & 101.3 \\
& Mean & 101.4 \\
& SD & 0.28 \\
& \% RSD & 0.28 \\
\hline \multicolumn{3}{c}{}
\end{tabular}

Where,

Set-1 $=$ As per method

Set $-2=$ Variation in flow by $+10 \%$

Set-3 = Variation in flow by $-10 \%$

Set- $4=$ Variation in column oven temperature by $+5{ }^{\circ} \mathrm{C}$

Set $-5=$ Variation in column oven temperature by $-5^{\circ} \mathrm{C}$

Set- $6=$ Variation in $\mathrm{pH}$ of the mobile phase as +0.2 .

Set-7 $=$ Variation in $\mathrm{pH}$ of the mobile phase as -0.2 .

Set- $8=$ Variation in detection wave length by $+5 \mathrm{~nm}$

Set- $9=$ Variation in detection wave length by $-5 \mathrm{~nm}$

\section{Solution stability}

RSD for assay of lactic acid reference and silver lactate sample during stability experiments was $0.25 \%$ and $0.33 \%$ respectively. The results from solution stability conformed that sample solution of lactic acid and silver lactate in water for assay analysis was stable for at least $24 \mathrm{~h}$. Results are summarized in Table 5

Table 5. Sample Solution stability

\begin{tabular}{ccc}
\hline Time, H & Area of Lactic acid & Cumulative, \%RSD \\
\hline Initial & 3044537 & - \\
$4 \mathrm{H}$ & 3042888 & 0.04 \\
$8 \mathrm{H}$ & 3041973 & 0.04 \\
$12 \mathrm{H}$ & 3055221 & 0.20 \\
$16 \mathrm{H}$ & 3050461 & 0.19 \\
$20 \mathrm{H}$ & 3060962 & 0.25 \\
$24 \mathrm{H}$ & 3068735 & 0.33 \\
\hline
\end{tabular}

\section{System suitability}

Tailing factor less than 2.0, similarity factor between 0.98 and 1.02 and RSD for lactic acid peak from the replicate injections less than $2.0 \%$ for all the system suitability study. Results are summarized in Table 6

Table 6. System suitability

\begin{tabular}{|c|c|c|c|}
\hline Experiment & Tailing factor & Similarity factor & $\%$ RSD \\
\hline $\begin{array}{l}\text { Repeatability, Linearity } \\
\text { (Silver lactate) }\end{array}$ & 1.6 & 1.00 & 0.07 \\
\hline $\begin{array}{l}\text { Robustness } \\
\text { (Flow,pH \& Temp minus) }\end{array}$ & 1.5 & 1.00 & 0.03 \\
\hline $\begin{array}{l}\text { Robustness (Temp plus) and Solution } \\
\text { stability }\end{array}$ & 1.5 & 0.99 & 0.06 \\
\hline Intermediate Precision & 1.3 & 1.00 & 0.29 \\
\hline Degradation, Linearity (Lactic acid) & 1.5 & 1.01 & 0.09 \\
\hline
\end{tabular}




\section{Conclusion}

The HPLC method developed for quantitative assay of silver lactate is precise, rapid and specific. Full validation of the method furnished satisfactory results for all the method validation data tested. The method was stability-indicating and can be conveniently used by quality control departments for analysis of assay of silver lactate. Moreover, the lower solvent consumption along with the short analytical run time of 10.0 min leads to cost effective chromatographic method

\section{Acknowledgment}

The authors would like to thank the management of Research and Development, Piramal Healthcare Ltd. for supporting this work. Cooperation from colleagues Analytical Research and Department is appreciated.

\section{References}

1. The Merck Index, $14^{\text {th }}$ Ed., Merck \& Co., USA, 2006, 578.

2. Melaiye A and Youngs W J, Expert Opinion on Therapeutic Patents, 2005, 15(2), 125-130.

3. Klasen H J, Burns, 2010, 26(2), 131-138.

4. Robert M Nalbandian, Raymond L Henry and Harvey S Wilks, J Biomed Mater Res., 1972, 6(6), 583-590.

5. Newman G R and Jasani B, J Pathol., 1998, 186(2), 119-125.

6. Butler M.J, Gardiner R.B and Day A W, Mycologia., 2005, 97(2), 312-319.

7. Tan Li, Wang Yu, Xiaoquan Liu, Huangxian Ju and Jieshou Li, J Chromatogr B, 2005, 814(2), 393-398.

8. Figueiredo I M, Pereira N R, Efraim P, Garcia N H, Rodrigues N R, Marsaioli A Jr, and Marsaioli A J, J Agric Food Chem., 2006, 54(12), 4102-6.

9. Maria G. Macedo, Marie-France Laporte and Christophe Lacroix J, Agric Food Chem., 2002, 50(7), 1774-1779.

10. Franco E J, Hofstetter H and Hofstetter O, J Pharm Biomed Anal., 2009, 49(4), 1088-1091.

11. Hasegawa Hisanori, Fukushima Takeshi, Lee Jen-Ai, Tsukamoto Kazuhisa, Moriya Kyoji, Ono Yoshikazu and Imai Kazuhiro, Anal Bioanal Chem., 2003, 377(5), 886-891.

12. Patricia S. Nassos, John E. Schade, Douglas King Jr A and Allan E. Stafford, J Food Sci., 2006, 49(3), 671-674.

13. Julia B. Ewaschuk, Jonathan M. Naylor and Wade A. Barabash, J Chromatogr B, 2004, 805(2), 347-351.

14. International Conferences on Harmonization.Q2(R) Validation of analytical Procedures, 1996, Geneva. 


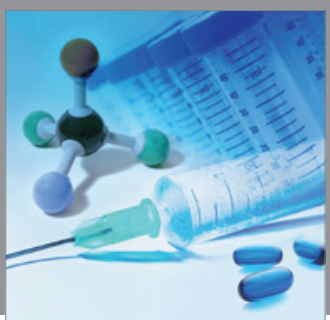

International Journal of

Medicinal Chemistry

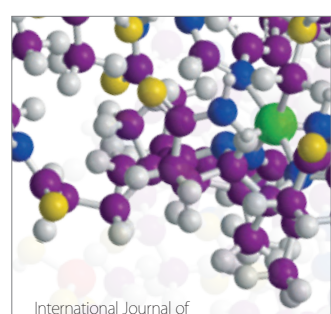

Carbohydrate Chemistry

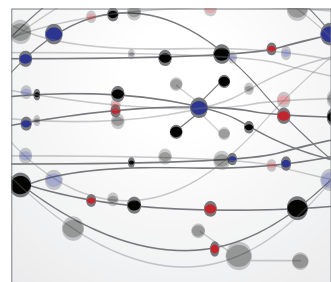

The Scientific World Journal
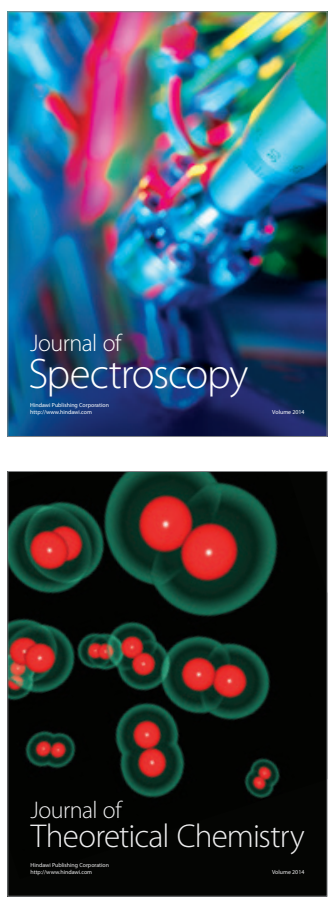
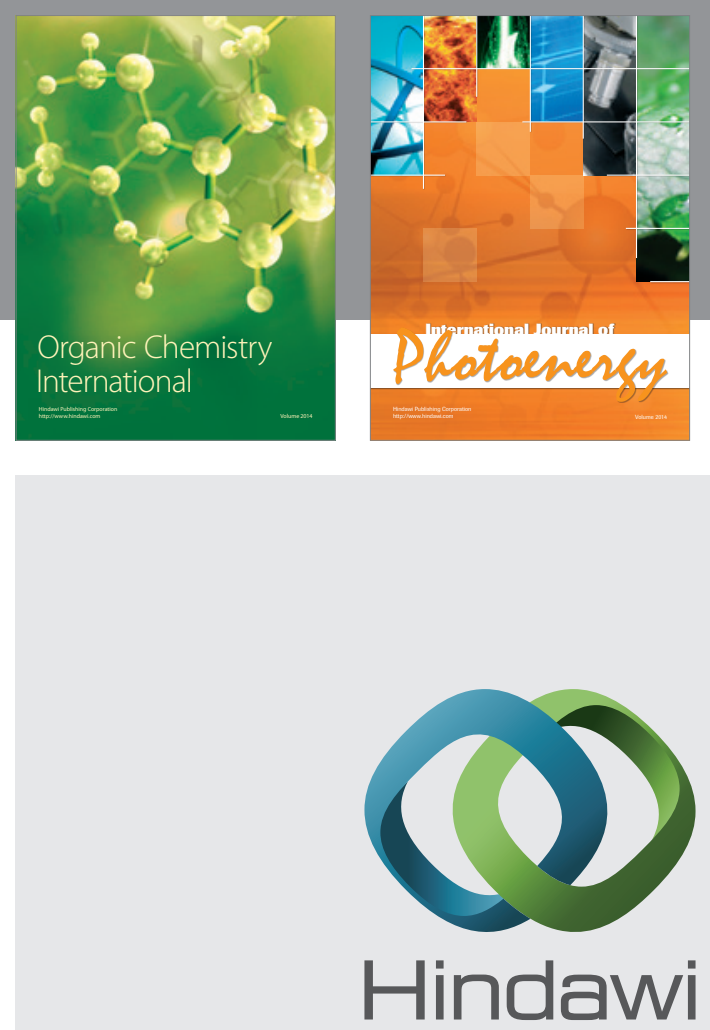

Submit your manuscripts at

http://www.hindawi.com
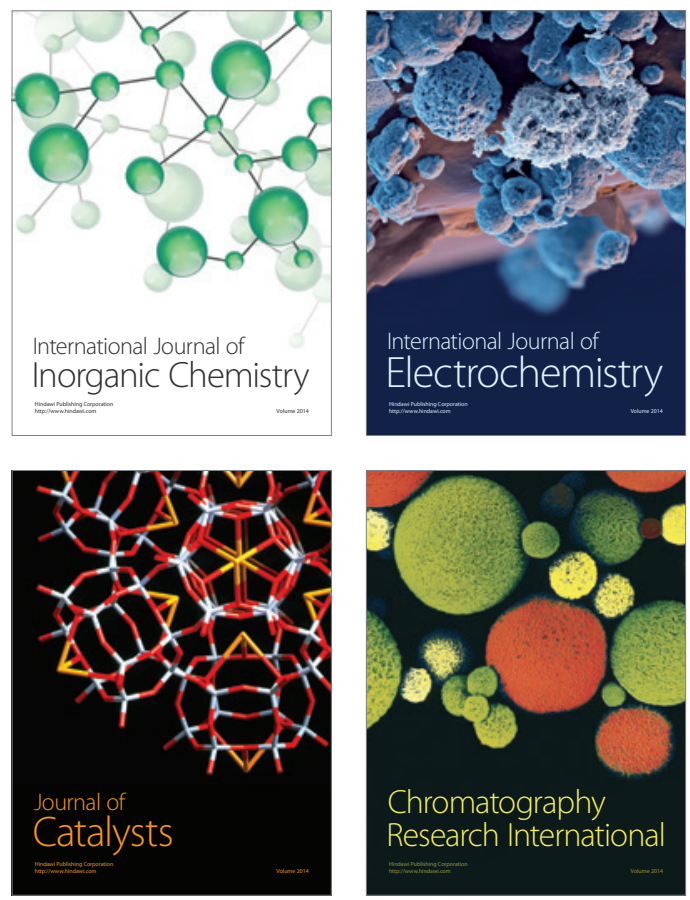
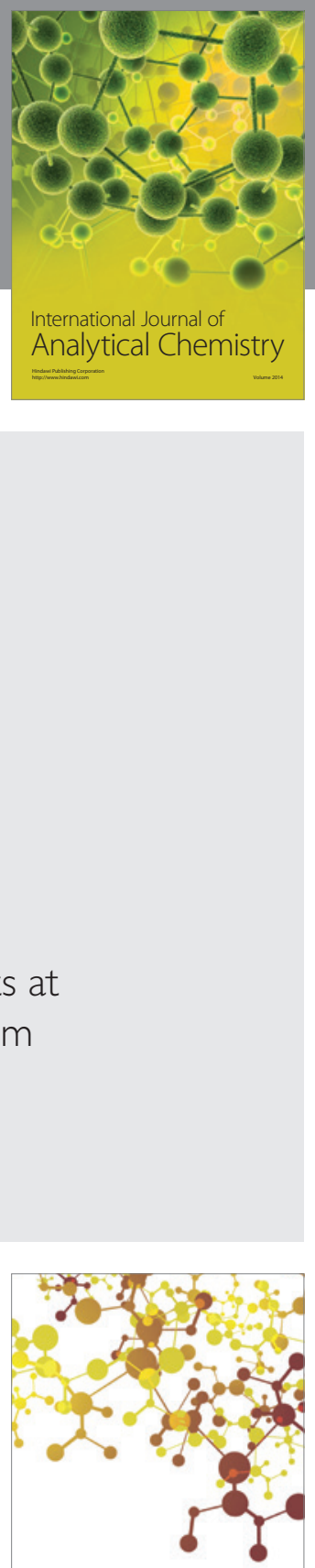

Journal of

Applied Chemistry
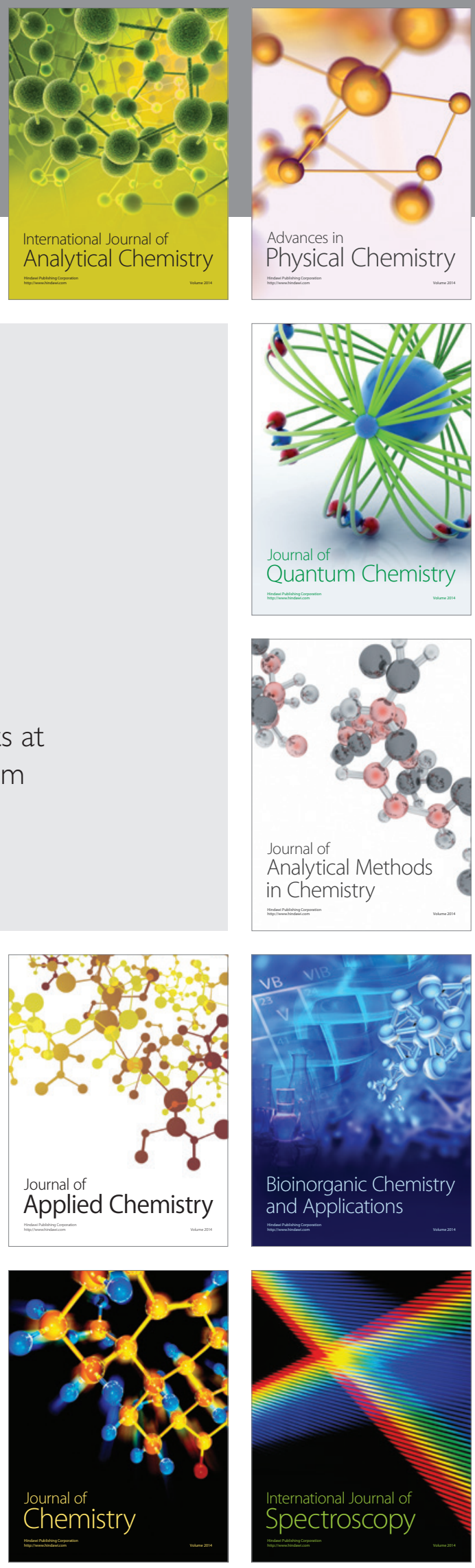